\title{
THE INFLUENCE OF FINANCIAL POLICIES ON EARNINGS MANAGEMENT, MODERATED BY GOOD CORPORATE GOVERNANCE
}

\author{
Wahidahwati \\ wahidahwati@gmail.com \\ Sekolah Tinggi Ilmu Ekonomi Indonesia Surabaya
}

\begin{abstract}
ABSTRAK
Penelitian ini menguji hubungan antara kebijakan keuangan (kebijakan hutang, kebijakan investasi, dan kebijakan dividen) dan manajemen laba yang dimoderasi oleh variabel kontekstual seperti mekanisme internal Tata Kelola Perusahaan. Secara khusus, penelitian ini menguji apakah variabel moderator mempengaruhi hubungan antara kebijakan keuangan dan manajemen laba. Sampel dalam penelitian ini adalah perusahaan sektor manufaktur yang terdaftar di Bursa Efek Indonesia (BEI) dan terdaftar di Bursa Efek Kuala Lumpur (KLSE) yang memberikan laporan keuangan tahunan dari tahun 2004 sampai 2010, Analisis data pada penelitian ini didasarkan pada data 2005-2010. Teori yang mendasari adalah teori keagenan. Hasil menunjukkan bahwa perusahaan-perusahaan yang terdaftar di BEI dan KLSE, tiga kebijakan (kebijakan hutang utang, dividen dan kebijakan investasi kebiajakan) berpengaruh terhadap manajemen laba (sebelum dampak GCG). GCG menyebabkan perbedaan dalam hasil perusahaan yang terdaftar di Bursa Efek Indonesia dan KLSE. Hasil untuk perusahaan yang terdaftar di Bursa Efek Indonesia setelah dampak dari GCG bahwa hanya kebijakan dividen dan kebijakan investasi yang mempengaruhi manajemen laba. Sebaliknya hasil kontras untuk perusahaan yang terdaftar di KLSE setelah dampak dari acara GCG bahwa hanya kebijakan kebijakan utang dan investasi yang mempengaruhi manajemen laba. Hasil untuk perusahaan yang terdaftar di KLSE ini menunjukkan bahwa manajemen yang lebih over-investasi, karena dana internal lebih banyak digunakan untuk investasi dan pembayaran utang.
\end{abstract}

Kata kunci: kebijakan hutang, kebijakan dividen, kebijakan investasi, manajemen laba, tata kelola perusahaan yang baik

\begin{abstract}
This study examines the relationship between financial policy (debt policy, investment policy, and dividend policy) and earnings management moderated by contextual variable such as the internal mechanism of Corporate Governance. Specifically, this study examines whether each moderated variables or the interaction some of them influence the relationship between financial policy and earnings management. The sample in this study is the manufacturing sector companies listed in Indonesia Stock Exchange (IDX) and listed in the Kuala Lumpur Stock Exchange (KLSE) that providing annual financial reporting from 2004 through 2010, Analysis data on this study are based on data 2005-2010. The theory underlying the agency theory. The results show that the listed companies in BEI and the KLSE, the three policies (debt debt policy, dividend and investment policy) effect on the management of earnings (before any impact of the GCG). Good corporate governance leads to differences in the results of companies listed on the Stock Exchange and the KLSE. Results for companies listed on the Stock Exchange after the impact of the GCG show that only the dividend policy and investment policies that affect the management of earnings. These results indicate that firms in Indonesia under Investment. In contrast results for companies listed on the KLSE after the impact of GCG show that policy of debt and investment policies affect the management of earnings. Results for companies listed on KLSE indicates that the more over-Investment management, the more widely used internal funds for investment and debt payments.
\end{abstract}


Keywords: debt policy, dividend policy, investment policy, earnings management, good corporate governance

\section{INTRODUCTION}

The managerial relation is one of the key agency problems since principal (shareholder) and agent (management) can have different interest and a conflict of interest. Whereas shareholder seek the maximization of their wealth and encourage the maximization of the firm's value, managers' interests are usually linked to the compensation both with money and perquisites. In turn, managers could be prone to run the company even in detriment of the firm's value provided that they could satisfy their own utility function through some financial decisions such as over investment,debt policy, over optimal diversification or taking risk beyond the optimal level for the company, return of dividend to shareholder/dividend policy. The that firm financial policy will appear on financial statement especially at the earnings infor mation.

Earnings information is important indicator for evaluating firm financial performance. Manager determine the short term reported earnings of their companies by : 1) Managing, providing leadership, and directing the use of resources in operation, 2) Selecting the timing of some non operating events, and 3) Choosing the accounting methods that are used to measure short term earnings. Most managers always exert a stable financial performance. They know that managing earnings can be part of mana gers' job. Growing systematic evidence supports the argument that earnings management is a common practice in firms. Managers of firms routinely manipulate or "manage" reported financial information in response to a wide variety of incentives with potentially significant consequences to the firm's management, investor, creditor, and others.

The level of earnings management will be higher if management has incentive and opportunity to do so. The opportunity to engage earnings management exists when the manager knows some things, which others do not. The existence of information asymmetry between firm management and firm shareholder is an necessary condition, which must be met for earnings management to exist. When information asymmetry is high, stakeholders do not have necessary resources, incentives or access to relevant information to monitor manager's action .

On the contrary, the Corporate Governance mechanism can decrease the conflict of interests between managers and shareholders. Because Conflict of interests required some mechanism to ensure the protection of investors' rights. Therefore, corporate governance arises as a set of constraints to shape th bargaining over the quasi-rents generated or the way used by the suppliers of finance in order to assure the return on their investment. More specifically, corporate governance focuses on the mechanisms to reduce the array of agency cost originated by the nexus of contracts in the firm. This research use internal corporate governance mechanism such as control of board of commissioner, board of director, shareholder and audit committee. So corporate governance mechanism can reduce management behavior to do earning management.

This research is motivated to extend previous earnings management research which focused on examining financial policy (debt, dividend and investment policy) and consequences of earnings management practices. Very little has been conducted in investigating environment surrounding earnings management practices. These studies consider corporate governance (CG) as condition that reduces the opportunity practice of earnings management.

This research was the comparative study between corporate listing in Indonesia Stock Exchange and the Kuala Lumpur Stock Exchange. Reasons for choosing Malaysia to be compared with Indonesia as 
an object of observation are as follows: 1). The growth rate of Indonesia and Malaysia are not far different meaning there are similarities in terms of economic growth. 2). Indonesian inflation rate higher than the country of Malaysia 3). The proportion of debt used by companies varies between countries both Indonesia and Malaysia. This difference is due to the differences in riskfree interest rate, risk premium of debt. Interest rates vary between countries due to economic conditions affecting interest rates. 4) Companies in the control of the family and concentrated ownership. Companies in Indonesia Malaysia, even in Asia are historically and sociologically owned and controlled by the family.

Aim of research is to investigate the moderating effect of Corporate Governance (CG) on the association between the financial policy (debt, dividend and investment policy) and the magnitude of earnings management.

The research problem are: Does financial policy (debt, dividend and investment policy) influence on Earning management, if moderated by corporate governance mechanism?

This research give some contribution to theory, concept and policy. 1). Contribution to theory, to extend association literature by examining the impact of investment opportunity set level, as a condition that represent the wider opportunity to practice earnings management, on the association between financial policy (debt, dividend and investment policy) and the magnitude of earnings management. Examining the interaction between investment opportunity set and financial policy (debt, dividend and investment policy) on the earnings management is important to the theory that investment opportunity set can increase magnitude of earnings management related to a number of incentives. This research also contributes to extend association literature by examining the impact of corporate governance, as a condition that represent the narrow opportunity to practice earnings management, on the association between financial policy (debt, dividend and investment policy) and the magnitude of earnings mana gement. Examining the interaction between corporate governance and financial policy (debt, dividend and investment policy) on the earnings management is important to the theory that corporate governance can decrease magnitude of earnings management that related to a number of incentives. 2). Contribution to concept, to positive accounting theory wish give empirical evidence about efforts management to hide corporate performance through deed earning management that based to implementation of financial policy. The result of this research will also be useful to investor for better understanding reported earnings. Investors should not naively use the accounting income numbers without any adjustment for manipulation possibility of reported income. 3). Contribution to policy, refer to standards setter. Accounting standard setter may find the result of this study useful for evaluating the mandated additional disclosure that give sufficient information for better understanding reported earning. Finally, the result of this research will be useful to auditor for incentives to hold responsible for better quality for financial reporting of firm.

\section{THEORITICAL REVIEW}

\section{Corporate Policy and Earning Manage- ment}

There is extensive previous literature. The effect of debt and debt covenants on earnings management. The finding have been consistent with the view that for firms with high levels of debt, greater income increasing accrual are undertaken in the years which the debt constraints are likely be binding and income decreasing accruals are undertaken in other years. An appealing explanation is that the managers' perceived cost of technical default of debt covenants is higher than the perceive loss in value 
resulting from managing the discretionary accrual. Therefore, they engage in income increasing accruals when the debt covenant are likely to be binding and in income decreasing to 'bank' some of the income for future periods of possible binding debt constraints. If this is true, in a pooled crosssectional analysis, irrespective of whether the debt constraints are binding or not, the magnitude of discretionary accrual must be significantly higher for firms with more debt than for firms with less debt. Gul et al., (2006) gave evidence that debt levels are also significantly associated with the magnitude of discretionary accruals, suggesting that managers of high-debt firms are more likely to manage earnings than low debt firms.

\section{HYPOTHESIS}

Influence of Corporate Policy (Debt Policy, Dividend Policy And Investment Policy) on Earnings Management (H1)

An imbalance of information between the company management with shareholders is an essential condition for the practice of earnings management. Gul et al, (2003); Fanani, (2006) found evidence that firms have high debt levels tend to carry out earnings management because it can reduce the accuracy of the information from the profits. It can also be concluded that the level of debt and earning management has a positive relationship.

The ratio of dividend payments and profits of the period. The ratio of dividend payments reflects the company's policy to pay the rights of shareholders, usually causing the positive sentiment from the market. Savov, (2006) found evidence that the announcement of dividend has a positive relationship with stock returns. This means there is a positive relationship between dividend policy with earnings management (Savov, 2006; Achmad, Subekti dan Sari, 2007).

Managers choose the level of investment spending could maximize shareholder wealth without considering the current interest in the company. So that the policy could lead to investment spending investors to profit management. With the above arguments, proposed the following research hypothesis:

$\mathrm{H}_{1}$ : Debt Policy, Dividend Policy And Investment Policy Affect Of Earnings Management.

Influence of Corporate Policy (Debt Policy, Dividend Policy and Invesment Policy) on Earning Management if Moderated byThe Corporate Governance Mechanism. (H2a, $\mathrm{H} 2 \mathrm{~b}, \mathrm{H} 2 \mathrm{C}$ )

Badera, (2006) found that the oversight mechanism, represented by board member has a relationship with the company's performance, in other words the greater the commissioners the more serious in managing the company's management to increase corporate performance. This can be concluded that the greater proportion of the board of commissioners will reduce management to manage earnings because they feel there is strict control of the board of commissioners.

Xie, Davidson and Dadalt, (2003) found that the audit committee from outside can protect the interests of shareholders from actions earnings management made by management. Carcello (2006), April Klein (2006), also found evidence that the audit committee is significant negatively related to behavior management in the earnings management .

While research conducted in Indonesia, there are differences such discoveries made by Rachmawati and Triatmoko, (2007) found that there is a negative influence and significance of the audit committee and discreationari Accrual, contrary Siallagan, and Machfoedz, (2006) found that the existence of the audit committee has a positive influence quality and value of corporate profits. Siallagan, and Machfoedz, (2006) found that leverage can reduce the conflict between the manager and the bondholder. 
Siallagan, and Machfoedz, (2006) found that leverage can reduce the conflict between the manager and the bondholder. Taswan, (2009), found that the debt has a positive relationship to company performance. This result means the management wants to be judged good performance in the market although the risk of company, where risk can be indicated by the debt that causes a risk of bankruptcy for the company. In order that the performance is always judged whether the companies have high debt will cause management to use methods that increase the accounting income.

From the above description, concluded that the research aims to see whether the presence of corporate governance policies will minimize the impact of debt on earnings management. Pratana and Machfoedz, (2003); Xie, Biao, Wallace and Peter, (2003) concluded that the independent commissioner could affect earnings management actions. In this study, measurement for the CG do not use measurements separated as above, but using the measurement of all indicators that form the internal control mechanism of the CG included (Board of Commissioners, the Audit Committee, as shareholders and management) by using factor score. Thus derived hypotheses:

$\mathrm{H}_{2 \mathrm{a}}$ : The negative effect of debt policy on the management of profit when controlled by Corporate Governance mechanism

Provision of dividend policy will give a positive signal to the market, means that the dividend policy will increase the market performance. Therefore the higher the pay out devidend policy will affect management behavior to manage earnings. It is therefore necessary internal controls such as nonexecutive directors, the board of commissioners is expected to weaken the influence of dividends policy on the earnings management. Savov, (2006) states to a certain level, the higher dividends the lower the company's performance because the compa- ny may lose investment opportunities due to lack of cash. So that a high dividend would encourage managers to manage earnings in order not seen their performance declined. The existence of the audit commit tee is expected to reduce the behavior of managers in the earnings management if associated with dividend policy. Large agency conflicts will occur in the condition if the number of audit committees are less and do not have financial expertise. Thus derived hypotheses:

$\mathrm{H}_{2 \mathrm{~b}}$ : Dividend Policy a Negative Effect on Earnings Management When Control led By Corporate Governance Mechanism.

However, shareholders raised gap that reinvest in projects with net present value of the negative is a form of efficiency and delays to their welfare, so that shareholders will respond to negative policies of such companies. In other words, if the company carrying out projects worth now positive, the investment will be taken positively by the market because it expected to generate investment income flows and cash flow will be the future that ultimately increase the value of the company. With the GCG it is expected that expenditure will reduce the company's investment management to profit management.

$\mathrm{H}_{2 \mathrm{C}}$ : Investment Policies Negative Effect on Earnings Management When is Controlled by The Internal Mechanism the Corporate Governance

\section{RESEARCH METHOD}

Population and Sample

Population of this study is all the manufacturing companies listing in the Indonesia Stock Exchange and the Kuala Lumpur Stock Exchange. The sampling technique was purposive sampling. Sample selection criteria in this study are:

1. Emiten which includes manufacturing companies. The use of a manufacturing industry group is intended to avoid the characteristic differences between manu- 
facturing firms and non-manufacturing. Besides manufacturing companies also have a higher sensitivity to any event or occurrence.

2. Emiten have included financial reporting as of December 31, 2005, 2006, 2007, 2008, 2009 and 2010. The choice of the based on the premise that as of December 31 is an audited report, so that financial statements can be more reliable.

3. Based on these criteria, the number of samples used in this study to sample as many as 228 companies listing on the Indonesia Stock Exchange and 168 for sample listing in Kuala Lumpur Stock Exchange.

\section{Measurement of Dependent Variables: \\ Measurement of Earnings Management}

The discretionary component of the total accrual is estimated with the modified Jones (1991) Discretionary accrual (DA) for each firm $I$ in industry $j$ are defined as the residual from the regression of total accrual (the difference between Cash from Operations and Net Income) on two factors that explain non discretionary accruals, the increase in revenue and the level of fixed assets subject to depreciation.

DAit $=$ TAit $/$ Ait- $1-\left[\beta_{1}\left(1 / A_{i t-1}\right)+\beta_{2}\left(\Delta \mathrm{REV}_{\text {it }^{-}}\right.\right.$

Where:

$$
\left.\left.\Delta \mathrm{REC}_{\mathrm{it}}\right) / \mathrm{A}_{\mathrm{it}-1}\right)+\beta_{3}\left(\mathrm{PPE}_{\mathrm{it}} / \mathrm{A}_{\mathrm{it}}\right)
$$

$\mathrm{DA}_{\mathrm{it}}=$ Discretionary accrual for firm $\mathrm{i}$ in year $\mathrm{t}$

$\mathrm{TA}_{\text {it }}=$ Total accruals for firm $\mathrm{I}$ in year $\mathrm{t}$

$\mathrm{A}_{\mathrm{it}-1} \quad=$ Total assets for firm $\mathrm{I}$ in year $\mathrm{t}$

$\triangle$ REVit $=$ Change in net sales for firm $I$ in year $\mathrm{t}$

$\Delta \mathrm{REC}_{\mathrm{it}}=$ Change in net receivable for firm $\mathrm{i}$ in year $\mathrm{t}$

$\mathrm{PPE}_{\mathrm{it}}=$ Gross property, plant and equipment for firm I in year $t$

Where $\beta_{1}, \beta_{2}$ dan $\beta_{3}$ are the industry-specific estimated coefficients from the following cross-sectional regression.

$$
\begin{aligned}
\mathrm{TA}_{\mathrm{it}} / \mathrm{A}_{\mathrm{it}-1}= & \beta_{1}\left(1 / \mathrm{A}_{\mathrm{it}-1}\right)+\beta_{2}\left(\Delta \mathrm{REV}_{\mathrm{it}}-\Delta \mathrm{REC}_{\mathrm{it}}\right) / \\
& \left.\mathrm{A}_{\mathrm{it}-1}\right)+\beta_{3}\left(\mathrm{PPE}_{\mathrm{it}} / \mathrm{A}_{\mathrm{it}}\right)+\varepsilon_{\mathrm{i}}
\end{aligned}
$$

\section{Measurement of Independent Variable Debt Policy}

Debt is measured as current and noncurrent borrowings divided by total asset. Because book values are used to write debt contracts this measure more accurately proxies for debt holder and shareholder conflicts than market-based measures (Tarjo 2005), (Wahyudi and Pawestri 2006)

Mathematically debt policy variable (LEV) can be formulated as follows:

$$
\begin{aligned}
\mathrm{LEV}_{\text {it }}= & \frac{\mathrm{NBU}_{\text {it }}}{\mathrm{A}_{\text {it }}} \\
\mathrm{LEV}_{\text {it }}= & \text { Leverage (debt policy) for firm } \mathrm{i} \text { in } \\
& \text { year } \mathrm{t} \\
\text { NBUit }= & \text { Book value of total debt for firm } \mathrm{i} \\
& \text { in year } \mathrm{t} \\
\text { Ait } \quad & \text { Total Asset for firm } \mathrm{i} \text { in year } \mathrm{t}
\end{aligned}
$$

\section{Dividend Policy}

Dividend Policy Variable $(\Delta \mathrm{DIVD})$ is collected using proxy of dividend payout ratio which is referred to by Ismiyanti \& Hanafi, 2003; Wahyudi and Pawestri, 2006.

Mathematically dividend policy ( $\triangle$ DIVD) can be formulated as follows:

$$
\text { DIVD }_{\text {it }} \frac{\text { DPS }_{\text {it }}}{\text { EPS }_{\text {it }}}
$$

$\Delta \mathrm{DIVD}=\mathrm{DIVD}_{\mathrm{it}}-\mathrm{DIVD}_{\mathrm{it}-1}$

Where :

DPS $_{\text {it }}$ : Divident per-share for firm $i$ in year $\mathrm{t}$

EPS $_{\text {it }}$ : Earning per-share for firm $\mathrm{i}$ in year $\mathrm{t}$

$\triangle$ DIVD : Changes in corporate dividend in year $\mathrm{t}$

\section{Invesment Policy}

Invesment Policy Variable (INV) is referred to by Hermeindit (2004).

Mathematically Invesment policy (INV) can be formulated as follows:

$\mathrm{INV}_{\text {it }}=\mathrm{AKI}_{\mathrm{it}}$

$$
\mathrm{PPE}_{\mathrm{it}}
$$

Where :

$\mathrm{INV}_{\text {it }}$ : Invesment for firm $\mathrm{i}$ in year $\mathrm{t}$ 
$\mathrm{AKI}_{\mathrm{it}}$ : Cash flow of Invetasi activity for firm $i$ in year $t$

$\mathrm{PPE}_{\mathrm{it}} \quad$ : Book value of fixed asset for firm $\mathrm{i}$ in year $\mathrm{t}$

Measurement of Moderating Variable: Good Corporate Governance Mechanism (GCG)

In this research by being in line with Klapper and Love, (2002); Ali syah, Butt and Hasan, (2009), the quality of corporate gover nance mechanism (CG) has been estimated by the use of following equetion.

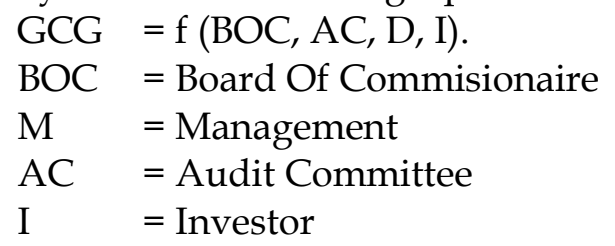

Above diagram represents the theoretical frame work for the measurement of quality of Good Corporate Governance. In each of company above mentioned functions has been identified and on the fulfillment of codes and literature's criteria marks has been assigned to each company. Each function has been given a weight on the basis of its importance as far as control on earnings management is concerned.
After allocating the marks and getting their respective weights, weighted mark have been calculated. To obtain the aggregate score of each company calculated weighted marks have been summed up. Criteria and form used for measuring of corporate gover nance mechanism is attached in appendix 1 .

\section{Control Variable: SIZE}

Firm size is included as a control variable in the analysis because it has been found to be associated with various firm characteristics. Firm size is measured as $\log$ natural of the book value of total assets, which is logged to normalize the variable and labeled LNASSET.

\section{THE SYSTEM CONTAINS TWO EQUA- TIONS}

Hypothesis $1 \mathrm{a}-1 \mathrm{c}$ (Model 1)

$\mathrm{DA}_{\text {it }}=\alpha_{1.1}+\beta_{1.1} \mathrm{LEV}_{\text {it }}+\beta_{1.2}$ DDIVDit + $\beta_{1.3} \mathrm{INV}_{\mathrm{it}}+\rho_{1.1} \mathrm{SIZE}_{\mathrm{it}}+\mathrm{e}_{\mathrm{it}}$

Hypothesis $2 \mathrm{a}-2 \mathrm{c}$ (Model 2)

$$
\begin{aligned}
\mathrm{DA}_{i t}= & \alpha_{3.1}+\beta_{3.1} \mathrm{LEV}+\beta_{32} \Delta \mathrm{DIVD}+\beta_{3.3 \mathrm{INV}} \\
& +\gamma_{3.1} \mathrm{CG}+\gamma_{3.2} \mathrm{LEV}{ }^{*} \mathrm{CG}+ \\
& \gamma_{3.3} \Delta \mathrm{DIVD}{ }^{*} \mathrm{CG}+\gamma_{3.4} \mathrm{INV}^{*} \mathrm{CG}+\rho_{3.1} \\
& \text { SIZE }+\mathrm{e}
\end{aligned}
$$

Table 1

Descriptive statistical

\begin{tabular}{ccccc}
\hline \hline Variabel & $\mathbf{N}$ & Rata-rata & Median & Deviasi Standar \\
\hline Sample of BEI & & & & \\
DA & 228 & $-0,028$ & $-0,0250$ & 0,1073 \\
LEV & 228 & 0,44001 & 0,4046 & 0,2210 \\
$\Delta$ DIVD & 228 & 1,4483 & 0,0058 & 21,1859 \\
INV & 228 & $-0,2020$ & 0,1645 & 0.2597 \\
GCG & 228 & 0,6079 & 0,6169 & 0,0906 \\
SIZE & 228 & 13,6941 & 13,4682 & 1,6058 \\
Sample of KLSE & & & & \\
DA & 168 & $-0,0011$ & 0,0015 & 0,0835 \\
LEV & 168 & 0,3835 & 0,3654 & 0,2000 \\
$\Delta$ DIVD & 168 & 0,3617 & 0,0008 & 3,0761 \\
INV & 168 & -2.1138 & $-0,1303$ & 17,7973 \\
GCG & 168 & 0,8653 & 0,8700 & 0,0609 \\
SIZE & 168 & 12,5519 & 12,2423 & 1,1736 \\
\hline
\end{tabular}


The above table shows that earnings management (DA) on companies listed on Indonesia Stock Exchange (BEI) had an average of 0.028 is higher when compared to companies listed on the KLSE had average earnings of the management of -0.001 , which both have the negative coefficient. This indicates that during the years of observation founded that both companies on the BEI and the KLSE routinely do practice earnings management, which management prefers policies that reduce earnings. Average investment rate (INV) on companies listed on the Indonesia Stock Exchange (BEI) in the amount of -0.2020 with a standard deviation of 0.2597 while the KLSE for the average investment rate of -2.1138 , with standard deviation of 17.7923 . These results indicate that variations of invesment in the KLSE larger than in the BEI, average of dividends (DIVD) in companies listed on Indonesia Stock Exchange (BEI) of 1.4483 while the KLSE for the average of dividend of 0.3617 . These results indicate that the variation dividend in the BEI larger than in the KLSE. Standard deviation of the other variables are relatively small in value, it shows that behavior of earnings management of firms in the sample are not too varied. Standard deviation values are not too big also shows that the deviation of each variable is not significant.

\section{TestingThe Classical Assumptions}

Test classical assumptions consists of normality test, multikolinierity test, autocorrelation test and heterokedastisitas test, where everything is free from interference, so that hypothesis testing can be done.

Results of Test Statistics: for Companies Listing on The Indonesia Stock Exchange (ISE) and The KLSE

$$
\begin{aligned}
\text { Model 1 } & \\
\left|D A_{i t}\right|= & \alpha_{1.1}+\beta_{1.1} L_{E V}+\beta_{1.2} \Delta \text { DIVD }_{\text {it }}+ \\
& \beta_{1.3} I_{\text {INV }}+\beta_{1.4} \text { GCG }+\rho_{1.1} \text { SIZE }_{\text {it }}+ \\
& \mathrm{e}_{\mathrm{it}}
\end{aligned}
$$

\begin{tabular}{lcccccc}
\hline \hline \multirow{2}{*}{ Variabel } & \multicolumn{3}{c}{ Indonesia } & \multicolumn{3}{c}{ Malaysia } \\
\cline { 2 - 7 } & B & t & Sig & B & t & Sig \\
\hline Model 1 & & & & & & \\
Intercept & 0,0580 & 0,917 & 0,360 & 0,0470 & 0,508 & 0,612 \\
LEV & 0,0806 & 2,460 & $0,015^{* *}$ & 0,0240 & 2.743 & $0,007^{* * *}$ \\
INV & 0,1390 & 5,217 & $0,000^{* * *}$ & 0,0210 & 2,739 & $0,007^{* * *}$ \\
$\Delta$ DIVD & 0,0008 & 2,632 & $0,009^{* *}$ & 0,0064 & 0,593 & 0,554 \\
GCG & $-0,1520$ & -1.938 & $0,054^{*}$ & $-0,1710$ & -2.14 & $0,034^{* *}$ \\
SIZE & $-0,0005$ & $-0,144$ & 0,910 & 0,0087 & 2,075 & $0,040^{* *}$ \\
$R^{2}$ & $0,118(0,094)$ & & & $0,152(0,120)$ & & \\
$F$ & $7,345^{* * *}$ & & & $4,714^{* * *}$ & & \\
\hline
\end{tabular}

${ }^{* * *}$ Statistically significant at $1 \%$

${ }^{* *}$ Statistically significant at the $5 \%$

* Statistically significant at $10 \%$

\section{Model 2:}

$\left|D A_{i t}\right|=\alpha_{2.1}+\beta_{2.1} \mathrm{LEV}_{\mathrm{it}}+\beta_{2.2} \Delta \mathrm{DIVD}_{\mathrm{it}}+\beta_{2.3} \mathrm{INV}_{\text {it }}+\gamma_{2.1} \mathrm{GCG}_{\mathrm{it}}+\gamma_{2.2} \mathrm{LEV}_{\text {it }}{ }^{*} \mathrm{GCG}_{\text {it }}+\gamma_{2.3} \Delta \mathrm{DIVD}_{\mathrm{it}}$ ${ }^{*} \mathrm{GCG}_{\text {it }}+\gamma_{2.4} \mathrm{INV}_{\mathrm{it}}{ }^{*} \mathrm{GCG}_{\mathrm{it}}+\rho_{2.1} \mathrm{SIZE}_{\mathrm{it}}+\mathrm{e}_{\mathrm{it}}$ 


\begin{tabular}{|c|c|c|c|c|c|c|}
\hline \multirow{2}{*}{ Variabel } & \multicolumn{3}{|c|}{ Indonesia } & \multicolumn{3}{|c|}{ Malaysia } \\
\hline & B & $\mathbf{t}$ & Sig & B & $\mathbf{t}$ & Sig \\
\hline \multicolumn{7}{|l|}{ Model 2} \\
\hline Intercept & 0,2410 & 4,580 & $0,000^{* \star \star}$ & 0,2580 & 4,264 & $0,000^{* * *}$ \\
\hline $\mathrm{LEV}_{\text {it }}$ & 0,0055 & 0,256 & 0,798 & 0,0399 & 2,411 & $0,017^{* *}$ \\
\hline $\mathrm{INV}_{\text {it }}$ & $-0,3300$ & $-4,224$ & $0,000^{\star * *}$ & $-0,0127$ & $-0,719$ & 0,473 \\
\hline$\Delta \mathrm{DIVD}_{\mathrm{it}}$ & $-0,0129$ & $-0,944$ & 0,346 & 0,0306 & 0,926 & 0,356 \\
\hline $\mathrm{GCG}_{\mathrm{it}}$ & $-0,0399$ & $-0,591$ & 0,555 & $-0,0041$ & -0.029 & 0,977 \\
\hline $\mathrm{LEV}_{\mathrm{it}}{ }^{*} \mathrm{GCG}_{\mathrm{it}}$ & 0,0506 & 0,593 & 0,554 & 0,3140 & 1,118 & 0,265 \\
\hline $\mathrm{INV}_{\mathrm{it}}{ }^{*} \mathrm{GCG}_{\mathrm{it}}$ & $-0,5010$ & $-4,714$ & $0,000^{* * *}$ & $-0,0078$ & 2,136 & $0,034^{* *}$ \\
\hline $\begin{array}{l}\Delta \text { DIVD }_{\text {it }} \\
{ }^{*} \mathrm{GCG}_{\mathrm{it}}\end{array}$ & $-0,0013$ & $-2,711$ & $0,007^{* * *}$ & $-0,0125$ & $-0,448$ & 0,655 \\
\hline $\mathrm{SIZE}_{\mathrm{it}}$ & $-0,0112$ & -3.465 & $0.001^{* * *}$ & 0,0106 & 2,517 & $0.013^{* *}$ \\
\hline$R^{2}$ (Adjusted) & $0,201(0,172)$ & & & $0,157(0,114)$ & & \\
\hline$F$ & $6,842^{* * *}$ & & & $3,633^{* * *}$ & & \\
\hline
\end{tabular}

${ }^{* * *}$ Statistically significant at $1 \%$

${ }^{* *}$ Statistically significant at the 5\%

* Statistically significant at $10 \%$

\section{Testing goodness of fit}

Model 1

$\mathrm{F}$ value for companies listing on the Indonesia Stock Exchange was 7.345 with a probability value of 0.000 is statistically significant. $R^{2}$ is 0.118 which means that the earnings management (DA) is explained by leverage, changes in dividends, investment, corporate governance and firm size by $11.8 \%$. The remaining $88.2 \%$ is explained by variables other variables which are not included in Model 1. So also for companies listing on the KLSE, F value is 4.714 with a probability value of 0.000 is statistically significant. Value of $\mathrm{R}^{2}$ is 0.152 which means the ability of independent variables explain the dependent variable of $15.2 \%$.

\section{Model 2}

$\mathrm{F}$ value for companies listing on the Indonesia Stock Exchange is 6.842 and the probability value of 0.000 , are statistically significant. Value of $R^{2}$ is 0.201 , which means that earnings management is explained by leverage, changes in dividends, investments, corporate governance and the interaction of $20.1 \%$. The remaining $79.9 \%$ is explained by other variables that are not included in Model 2. So also for companies listing on the KLSE, F value is 3.633, the probability value of 0.001 are statistically significant. Value of $\mathrm{R}^{2}$ is 0.157 , which means the ability of independent variables explain the dependent variable of $15.7 \%$. The remaining $84.3 \%$ is explained by other variables that are not included in Model 2.

\section{Hypothesis Testing Results}

a. Analysis for company that listing in Indonesia Stock Exchange

Model 1

On Model 1, the coefficient of the variable LEV $\left(\beta_{1.1}\right)$ is 0.0806 and $t$ value of 2.460 with a probability value 0.015 , thus statistically significant at the 5\% level according to the predictions. This means that the greater the level of corporate debt policy, the greater the level of earnings management (DA). The results are consistent with previous studies that managers in companies with higher debt levels in the company's capital structure will provide a higher risk of failure (bankruptcy risk) so that management has a greater motivation to manage earnings 
in order to avoid or reduce the risk of capital structure, (Assih, 2004; Gul et al, 2003; Fanani, 2006).

Coefficients of DIVD $\left(\beta_{1.2}\right)$ is 0.0008 and $\mathrm{t}$ value of 2.632 with a probability value 0.009 , thus statistically significant at the $1 \%$ level. Evidence showed any effect of dividend policy on the level of earnings management. These results support research conducted by (Savov, 2006; Achmad, Subekti dan Sari, 2007). These results show support for agency theory which states a conflict between management and shareholders with respect to dividend policy. This conflict occurs because shareholders have a tendency to prefer dividends distributed in large numbers, because it has a high certainty, otherwise the management does not like big dividends, as it will reduce management utility that is caused by the smaller funds who is in control.

Coefficient of the variable INV $\left(\beta_{1.3}\right)$ is 0.1390 and $t$ value of 5.217 with a probability value 0.000 , thus statistically significant at the 5\% level. This means that the management of the greater profits made by companies have a large investment. These results are consistent with research conducted by Savov (2006). These results indicate that investment spending is intended to maximize current shareholder wealth without considering the interests of the compa nies concerned, so that management tends to invest too much to hope for a big profit without considering the risk of the company, and manage earnings in order performance looks good by the investor.

GCG variable coefficients $\left(\beta_{1.4}\right)$ is -0.152 and the value of -1.938 with a probability value 0.054 , although weak statistically signi ficant at the $10 \%$. Direction of the negative coefficient indicates that the effective internal oversight of corporate governance, the smaller of management to manage earnings. On Model 1, the coefficient of the variable Size ( $\rho 1.1)$ is -0.00053 and the value of -0.114 with a probability value of 0.910 . This means the size of the company's management had no effect on earnings.

\section{Model 2}

Hypothesis of $\mathrm{H}_{2 \mathrm{~A}}$ tested by $\mathrm{t}$ value to test the significance of the partial coefficient on $\mathrm{LEV}^{*} \mathrm{GCG}$. Impact of GCG on the relationship pemoderated LEV with DA indicated by the coefficient of $\mathrm{LEV}^{*} \mathrm{GCG}\left(\gamma_{2.2}\right)$. Coefficient of the interaction between a com pany's financial leverage and corporate governance $\left(\gamma_{2.2}\right)$ is 0.051 . $t$ value of this coefficient is 0.593 with a probability value of 0.554 . Concluded that the $\mathrm{H}_{02 a}$ can't rejected. Empirical evidence is unable to support the research hypothesis $\left(\mathrm{H}_{2 \mathrm{~A}}\right)$ that influence a company's financial leverage at the level of earnings management decreases with increasing the effectiveness of internal control of GCG. The results are not significant due to companies in Indonesia for the formation of a audit committee effective begin year of 2004, so the supervision of the audit committee has not been done. In addition it has not been effective as a lack of supervision of the commissioner and the audit committee members who have financial expertise.

Hypothesis of $\mathrm{H}_{2 \mathrm{~B}}$ was tested by examining the significance of the coefficient of the interaction between a firm's dividend by GCG (DIVD * GCG) in Model 2. Interaction coefficients DIVD*GCG $\left(\gamma_{2.3}\right)$ shows the value of -0.0013 and the $t$ value is -2.711 with probability value of 0.007 . At $5 \%$ significance level, it was concluded that $\mathrm{H}_{02} \mathrm{c}$ successfully rejected. Coefficient indicates the direction a positive direction, these results indicate that corporate governance in particular for internal control in Indonesia could weaken the relationship of dividends to earnings management. So the empirical evidence suggests that the evidence supports the hypothesis of the research $\left(\mathrm{H}_{2 \mathrm{~B}}\right)$.

Hypothesis of $\mathrm{H}_{2 \mathrm{C}}$ was tested by exami ning the significance of the coefficient of the interaction between investment companies with corporate governance (INV*GCG). Coefficient of INV*GCG $\left(\gamma_{2.4}\right)$ is $-0,501$ and the value is -4.714 with probability value of 0.000 . At $5 \%$ significance, it was concluded 
that $\mathrm{H}_{02 c}$ successfully rejected. So the empiri cal evidence suggests that the evidence supports the research hypothesis $\left(\mathrm{H}_{2 \mathrm{C}}\right)$. This means that the effectiveness of internal controls corporate governance (GCG) pemoderated influence on corporate investment relations to the level of earnings management. These results indicate that the investment problem is a very important issue to gain effective control of the board and audit committee so that management is not free to manage for both profit and efficiency objectives of management for opportunistic purposes.

\section{b. Analysis for Company That Listing In Kuala Lumpur Stock Exchange. Model 1}

On Model 1, the coefficient of the variable LEV $\left(\beta_{1.1}\right)$ are 0.024 and 2.743 for the value of $t$ value with probability value of 0.007 , thus statistically significant at the $5 \%$ level according to the predictions. This means that the higher levels of corporate leverage, the greater the level of accrual accounting under management. The results are consistent with previous studies that managers in companies with higher debt levels have a greater motivation to manage earnings in order to avoid or reduce the risk of capital structure (Assih, 2004).

DIVD variable coefficients $\left(\beta_{1.2}\right)$ is 0.0064 and $t$ value of 0.593 with a probability value 0.554 , thus not statistically significant. Evidence showing no effect of devidend policy on the level of earnings management. Although not significant but the coefficient indicates a positive direction signal in accordance with the theory which states that dividends provide a positive signal to the market and increase the stock price (firm value). These results are consistent with (Yurianto, 2000).

On Model 1, the coefficient of the variable INV $\left(\beta_{1.3}\right)$ is 0.0210 and $t$ value of 2.739 with a probability value of 0.007 , thus statistically significant at the 5\% level. This means that the management of the greater profits made by companies have a large investment. These results are consistent with the results of the companies listing on the Stock Exchange and the result is also consistent with (Savov, 2006).

Coefficient of GCG $\left(\beta_{1.4}\right)$ is 0.1710 and the value of -2.140 with a $t$ calculation proba bility value 0.034 , thus statistically significant at the $5 \%$ level. This means more effective internal controls of the smaller GCG management to manage earnings.

Firm size as control variables is expected to have a positive impact on the accrual basis of accounting under management, because the larger the company the more likely managers to manage earnings to avoid or reduce the cost of political action (Watts and Zimmerman, 1978; Moses, 1987). Coefficient of the Size $\left(\rho_{1.1}\right)$ is 0.0087 and $t$ value of 2.075 with a probability kalkulasian value 0.040 , thus statistically significant at the 5\% level. This means that the larger the size of the company, the greater the chance of management to manage earnings.

\section{Model 2}

Hypothesis of $\mathrm{H}_{2 \mathrm{~A}}$ tested by $\mathrm{t}$ value to test the significance of the partial coefficient on $\mathrm{LEV}^{*} \mathrm{GCG}$. GCG variables influence the relationship pemoderasian LEV with DA indicated by the coefficient of $\mathrm{LEV}^{*} \mathrm{GCG}$ $\left(\gamma_{2.2}\right)$. Coefficient of the interaction between a company's financial leverage and corporate governance $\left(\gamma_{2.2}\right)$ is 0.314 . $t$ value of this coefficient is 1.118 with a probability value of 0.265 . At a significance level of $5 \%$, it was concluded that the $\mathrm{H}_{02 a}$ not be denied. Empirical evidence is unable to support the research hypothesis $\left(\mathrm{H}_{2 \mathrm{~A}}\right)$ that influence a company's financial leverage at the level the greater earnings management by increasing the effectiveness of internal control of GCG. The results were not significant in Malaysia, possibly because most of the sampled companies studies suggest a family relationship between shareholders, management and board of Commissioner, so that the 
internal controls of the GCG is not desirable, particularly with regard to the debt policy.

Hypothesis of $\mathrm{H}_{2 \mathrm{~B}}$ was tested by examining the significance of the coefficient of the interaction between dividend companies and corporate governance (GCG*DIVD) Inte raction coefficients DIVD* GCG $\left(\gamma_{2.3}\right)$ shows the value of -0.0125 and the $t$ value is -0.448 with probability value of 0.655 . At a significance level of $5 \%$, it was concluded that $\mathrm{H}_{02 \mathrm{~b}}$ can not be denied. So the empirical evidence suggests that the evidence did not support the research hypothesis $\left(\mathrm{H}_{2 \mathrm{~B}}\right)$. This means it can not prove that the great variable GCG treating the negative influence of dividends on the level of earnings management.

H2C hypothesis was tested by examining the significance of the coefficient of the interaction between investment companies with corporate governance (INV*GCG) in Model 2. Coefficient of INV * GCG $\left(\gamma_{2.4}\right)$ is 0.00784 and $\mathrm{t}$ kalkulasian value is 2.136 with probability value of 0.034 . At a significance level of $5 \%$ one hand, it was concluded that $\mathrm{H}_{02 c}$ rejected. So the empirical evidence shows evidence supports the hypothesis of the study $\left(\mathrm{H}_{2 \mathrm{C}}\right)$. This means that the effectiveness of internal controls corporate gover nance moderated influence on corporate investment relations to the level of earnings management. The results indicate that the more effective internal oversight of corporate governance it will reduce the impact of investment on the behavior of management to manage earnings.

\section{CONCLUSIONS AND RECOMMENDA- TIONS \\ Conclusion}

From the research results can be conclu ded that; The first, dividend policy in both countries (Indonesia and Malaysia) none of the motivators of management to manage earnings, although moderated by the GCG results were not significant. Second, Indonesia and Malaysia supports the pecking order theory and signaling theory to link debt policy and investment policy. This indicates that companies in Indonesia and Malaysia stock market are great use of debt, and investing their greater funding through debt. Third, Internal control of corporate governance (GCG) in Indonesia is much lower than in Malaysia, so GCG can not moderate the relationship of financial policy (debt policy and dividend policy) on the earnings management.

\section{RECOMMENDATION}

Recommendations can be given in this study is: The first, next study is expected to use other of earnings management measures by using models offered by Whelan and McNamara (2004). The difference with the old model is, discretionary accruals that are broken down into components of shortterm and long-term. Therefore, the separation is expected to further elucidate the role of each component of discretionary accruals in earnings management. The use of these new models aim to see the consistency of the results so the results can be more benefi cial to the company. Second, to examine in other industries with a longer observation in order to provide better results. Third, to improve internal control index of corporate governance in this study for example by adding the points relevant to the question by sending a questionnaire. The next study is also expected to connect the company's policy on the management of earnings by looking at the market reaction, in order to further strengthen the results of the analysis. Finally, If you want to continue or expand this research is expected to consider funding constraints (high/low) as the Karo (2004) did.

\section{REFERENCES}

Achmad, K, Subekti I, dan Sari A. 2007. Investigasi Motivasi Strategi Manajemen Laba pada Perusahaan Publik di Indonesia, Prosiding Simposium Nasional Akuntansi 10 Makasar.

Andreas. 2007. Pengaruh Tata Kelola Korporasi, Pengungkapan Korporasi, dan Risiko Keuangan terhadap Mana- 
jemen Laba dan Kinerja Korporasi, Disertasi Universitas Brawijaya.

Audra. 2005. The Determinants of Corporate Board Size and Composition: An Empirical Analysis, JEL Publikasi Internet, Version 3-0-9.

Badera, I N. 2006. Pengaruh Corporate Governance terhadap Kinerja Perusahaan Dengan Budaya Organisasi sebagai Variabel Pemoderasi. Audi Jurnal Akuntansi Dan Bisnis 1(1).

Beiner. S., W. Drobetz, F. Schmid and H. Zimmermann. 2003. The Role of Exchange Different, B Journal of Business, Finance and Accounting, 621-633

Business Week (Berita Bisnis Internasional) www.businessweek.com/

Chambers, D. J. 2003. Earnings Persistence and Accrual Anomaly. Working Paper., University of Illions at Urbana-Champaign: 1-29

Cornett M. M., J. Marcuss., Sounders and H. Tehranian. 2006. Earnings Management, Corporate Governance, and True Financial Performance. Working Paper. http://Papers.ssrn.com

Department of Statistic: http;//www.statistics. gov.my/

Masdupi, Erni. 2005. Analisis Dampak Struktur Kepemilikan pada Kebijakan Hutang dalam Mengontrol Konflik Keagenan, Jurnal Ekonomi dan Bisnis Indonesia 2(1): 57-69.

Pagalung,G.2003. Pengaruh Kombinasi Keunggulan dan Keterbatasan Perusahaan terhadap Set Kesempatan Investasi (IOS), Jurnal Riset Akuntansi Indonesia 6(3): 249-263.

Holydia Lestari. 2004. Pengaruh Kebijakan Hutang, Kebijakan Deviden, Risiko dan Profitabilitas Perusahaan Terhadap Set Kesempatan Investasi (IOS). Simposium Nasional Akuntansi VII : 1059-1071.
Jones, J. 1991, Earnings Management During Import Relief Investigations. Journal Accounting Research 29, pp. 193-228.

Komite Nasional Kebijakan Governance. 2004. Pedoman Tentang Komisaris Inde penden. http://www.governanceindonesia. or.id/main.htm.

Midiastuty, P,P dan Mas'ud Mahfoedz, Mas'ud. 2003. Analisis Hubungan Mekanisme Corporate Governance dan Indikasi Manajemen Laba. Simposium Nasional Akuntansi VI. IAI, 2003

Riahi-Belkoui,A. 2003. Anticipatory Income Smoothing and The Investment Opportunity Set: An Empirical Test of The Fudenderg and Tirole 1995 Model, Review of Accounting and Finance, 2.2: ABI/INFORM Global

Savov, S. 2006. Earings Management, Invesment, and Dividend Payment. Working Paper. University of Mannhein. http//:www.google.com. Accesed on 22 Desember 2008

Sri Hasnawati. 2005. Dampak Set Peluang Investasi Terhadap Nilai Perusahaan Publik di Bursa Efek Jakarta, JAAI 9(2): 153-163.

Taswan, 2009. Analisis Pengaruh Insider Ownership, Kebijakan Utang dan Dividen Terhadap Nilai Perusahaan serta Faktor-Faktor yang Mempengaruhinya. Jurnal Bisnis dan Ekonomi 10(2): 162-181

Weekly Financial Review-Singapore (Berita ekonomi Singapore, Malaysia dan Thailand) www.oub.com.sg/mkreview. htm/

Worldwide data (analisis pasar dan ekonomi) www.businessmonitor.co.uk/

Xie, Biao., Wallace N. Davidson and Peter J. Dadalt.2003. Earning Management and Corporate Governance; The Roles of The Board and The Audit Committee. Journal of Corporate Finance 9: 295-316 


\section{Appendix 1}

\section{Measurement of GCG}

Scoring Criteria and their weights.

Presence of Board of Commisionar: weight 45\%, Audit Committee: Weight 20\%, Management: Weight 20\%, Shareholder: Weight 15\%

1. BOARD OF COMMISSIONER (45\%)

a. COM_SIZE (Size of commissioner):

Range :

$0-3$

Score

$4-6$

2

$6-8$

4

$9-11$

6

$>11$

8

10

b. COM_IND (Independent commisionar)

Range:

$0 \%-20 \%$

Score

$21 \%-40 \%$

2

$41 \%-60 \%$

4

$61 \%-80 \%$

6

81 and above

8

c. \%COMOWN

Range:

$0 \%-20 \%$

$21 \%-40 \%$

10

$41 \%-60 \%$

Score

$61 \%-80 \%$

2

81 and above

4

6

8

d. AUD (Big four)

Range

Ya

10

Tidak

\section{AUDIT COMMITTEE (20\%)}

a. AUD_SIZE (Size of Audit Committee):

Range:

$0-3$

Score

$4-6$

2

$6-8$

4

$9-11$

6

$>11$

10

b. AUD_IND (Independent Audit Committee)

Range:

$0 \%-20 \%$

$21 \%-40 \%$

Score

$41 \%-60 \%$

2

$61 \%-80 \%$

6

81 and above 
c. FINEXPERT

Range

Ya

Score

Tidak

3. MANAGEMENT (20\%)
a. DIR_SIZE
Range:
$0-3$
Score
$4-6$
2
$6-8$
4
6
$9-11$
8
$>11$
10
b. M_OWN (Managerial ownership)
Range:
$0 \%-20 \%$
Score
$21 \%-40 \%$
2
$41 \%-60 \%$
4
$61 \%-80 \%$
6
81 nd above
10
c. Family relations
Range
Yes
Score
No
0
5

\section{SHAREHOLDER (15\%)}

INST_OWN (Institutional Ownership)

Range:

$0 \%-20 \%$

Score

$21 \%-40 \%$

10

$41 \%-60 \%$

8

$61 \%-80 \%$

6

81 and above

4

2 